\title{
Dam removal and anadromous salmonid (Oncorhynchus spp.) conservation in California
}

\author{
Rebecca M. Quiñones • Theodore E. Grantham • \\ Brett N. Harvey $\cdot$ Joseph D. Kiernan • \\ Mick Klasson · Alpa P. Wintzer · Peter B. Moyle
}

Received: 25 October 2013/Accepted: 21 May 2014/Published online: 4 June 2014

(C) The Author(s) 2014. This article is published with open access at Springerlink.com

\begin{abstract}
Dam removal is often proposed for restoration of anadromous salmonid populations, which are in serious decline in California. However, the benefits of dam removal vary due to differences in affected populations and potential for environmental impacts. Here, we develop an assessment method to examine the relationship between dam removal and salmonid conservation, focusing on dams that act as complete migration barriers. Specifically, we (1) review the effects of dams on anadromous salmonids, (2) describe factors specific to dam removal in California, (3) propose a method to evaluate dam
\end{abstract}

Electronic supplementary material The online version of this article (doi:10.1007/s11160-014-9359-5) contains supplementary material, which is available to authorized users.

R. M. Quiñones $(\bowtie) \cdot$ T. E. Grantham ·

A. P. Wintzer · P. B. Moyle

Center for Watershed Sciences, University of California-

Davis, 1 Shields Ave, Davis, CA 95616, USA

e-mail: rmquinones@ucdavis.edu

B. N. Harvey

California Department of Water Resources, 3500

Industrial Blvd, West Sacramento, CA 95691, USA

J. D. Kiernan

Southwest Fisheries Science Center, National Oceanic and Atmospheric Administration, La Jolla, CA 92037, USA

M. Klasson

2814 Tiber Ave, Davis, CA 95616, USA removal effects on salmonids, (4) apply this method to evaluate 24 dams, and (5) discuss potential effects of removing four dams on the Klamath River. Our flexible rating system can rapidly assess the likely effects of dam removal, as a first step in the prioritization of multiple dam removals. We rated eight dams proposed for removal and compared them with another 16 dams, which are not candidates for removal. Twelve of the 24 dams evaluated had scores that indicated at least a moderate benefit to salmonids following removal. In particular, scores indicated that removal of the four dams on the Klamath River is warranted for salmonid conservation. Ultimately, all dams will be abandoned, removed, or rebuilt even if the timespan is hundreds of years. Thus, periodic evaluation of the environmental benefits of dam removal is needed using criteria such as those presented in this paper.

Keywords Dam effects · Pacific salmon - Steelhead · Climate change $\cdot$ Klamath River $\cdot$ Mediterranean environments

\section{Introduction}

Dams are present in nearly all California watersheds. Whether constructed for flood control, irrigation, urban water use, or hydroelectric power generation, dams alter the movement of water, sediment, nutrients and organisms in riverine ecosystems (Magilligan and 
Table 1 Anadromous salmonid taxa found in California, their status and level of impact sustained from dams

\begin{tabular}{|c|c|c|c|c|}
\hline Species & Taxa & $\begin{array}{l}\text { Federal/state } \\
\text { listing }\end{array}$ & Status & $\begin{array}{l}\text { Impact from } \\
\text { dams }\end{array}$ \\
\hline \multirow{8}{*}{$\begin{array}{l}\text { Chinook salmon, Oncorhynchus } \\
\text { tshawytscha }\end{array}$} & Upper Klamath-Trinity spring & - & $\mathrm{E}$ & High \\
\hline & Upper Klamath-Trinity fall & - & $\mathrm{V}$ & Critical \\
\hline & $\begin{array}{l}\text { Southern Oregon Northern California } \\
\text { Coast fall }\end{array}$ & - & WL & Moderate \\
\hline & California Coast fall & T/- & V & Moderate \\
\hline & Central Valley winter & $\mathrm{E} / \mathrm{E}$ & $\mathrm{V}$ & Critical \\
\hline & Central Valley spring & $\mathrm{T} / \mathrm{T}$ & $\mathrm{V}$ & Critical \\
\hline & Central Valley fall & - & V-E & High \\
\hline & Northern California Coast & T/- & $\begin{array}{l}\text { WL- } \\
\text { E }\end{array}$ & Moderate \\
\hline \multirow[t]{6}{*}{ Steelhead, Oncorhynchus mykiss } & Klamath Mountains Province winter & - & WL & Moderate \\
\hline & Klamath Mountains Province summer & - & $\mathrm{E}$ & High \\
\hline & Central California Coast winter & T/- & $\mathrm{V}$ & Moderate \\
\hline & Central Valley & $\mathrm{T} /-$ & $\mathrm{V}$ & High \\
\hline & South Central California Coast & $\mathrm{T} /-$ & V & Moderate \\
\hline & Southern California & E/- & $\mathrm{E}$ & High \\
\hline \multirow[t]{2}{*}{ Coho salmon, Oncorhynchus kisutch } & Central Coast & $\mathrm{E} / \mathrm{T}$ & $\mathrm{E}$ & Moderate \\
\hline & $\begin{array}{l}\text { Southern Oregon Northern California } \\
\text { Coast }\end{array}$ & $\mathrm{E} / \mathrm{T}$ & $\mathrm{E}$ & Moderate \\
\hline Chum salmon, Oncorhynchus keta & N/A & - & $\mathrm{E}$ & Moderate \\
\hline Pink salmon, Oncorhynchus gorbuscha & N/A & - & $\mathrm{E}$ & Low \\
\hline $\begin{array}{l}\text { Coastal cutthroat trout, Oncorhynchus } \\
\text { clarki clarki }\end{array}$ & N/A & - & WL & Low \\
\hline
\end{tabular}

Most taxa have formal recognition as distinct management units by state and federal agencies. We provide both federal listing status and status from Katz et al. (2013) with $T$ threatened, $E$ endangered, $V$ vulnerable and $W L$ watchlist. "Impact from dams" measures the magnitude of adverse impacts on specific runs

Nislow 2005; Graf 2006). This disruption of longitudinal connectivity changes the structure of biotic communities and the function of ecosystems (Ward and Stanford 1983; Knighton 1998; Wohl 2012), frequently with adverse consequences for native species (Marchetti and Moyle 2001).

Anadromous Pacific salmon and trout (salmonids; Oncorhynchus spp.) are particularly vulnerable to impacts of dams, especially dams that prevent migration between spawning and rearing habitats (Hanak et al. 2011). Salmonids in California are blocked from about $45 \%$ of historical habitats in major mainstem rivers but percentages vary by location. In California's Central Valley, for example, dams have blocked access to more than $80 \%$ of historical salmonid spawning areas (Yoshiyama et al. 1998; Lindley et al. 2006). Recent status assessments (Moyle et al. 2008;
Katz et al. 2013) have highlighted that nearly all of California's native anadromous salmonids are in serious decline (Table 1). Dams negatively affect all of the state's anadromous salmonids (Moyle et al. 2008) and are significant contributors to the decline of $43 \%$ of the taxa (Katz et al. 2013).

Since the 1850s, declining numbers of California's anadromous salmonids have been attributed, in part, to dams that blocked migration (Groot and Margolis 1991; Yoshiyama et al. 1998; Fig. 1). Consequently, there have been many attempts to mitigate for loss of salmon and steelhead Oncorhynchus mykiss trout due to dams and their operations. Starting in 1870, the California State Legislature passed a series of clearlystated laws to protect fish from the impacts of dams (Börk et al. 2012). The present manifestation of these laws is Fish and Game Code $\S 5937$, which states, "the 
Fig. 1 Anadromous salmonid habitat, accessible and blocked by dams, in major California rivers (modified from Hanak et al. 2011)

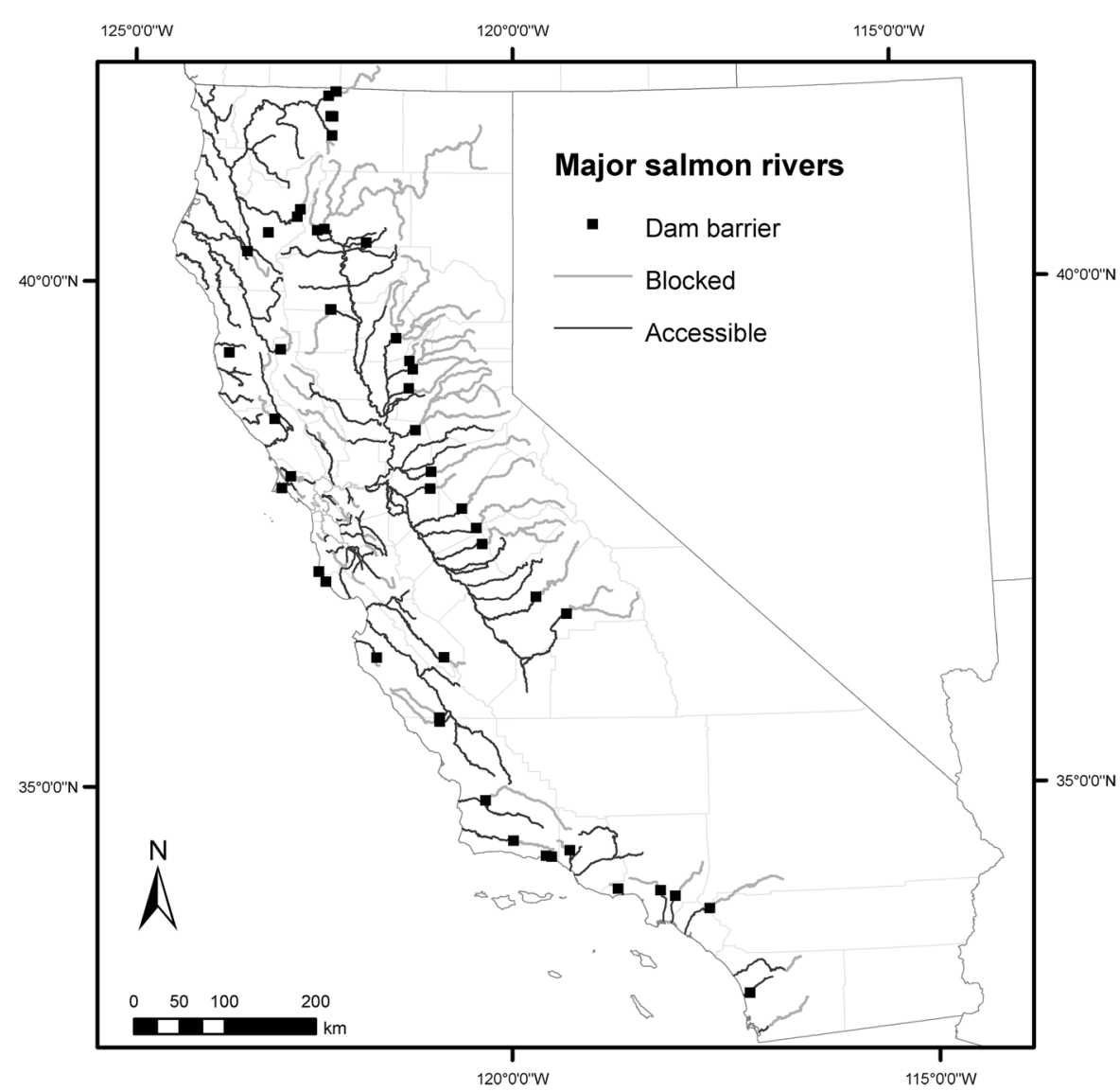

owner of any dam shall allow sufficient water at all times to pass over, around, or through the dam, to keep in good condition any fish that may be planted or exist below the dam." Despite this mandate, the majority of dams constructed in California during the last century were designed and operated with little consideration for their impact on fishes (Börk et al. 2012). In particular, most large dams do not provide structures for fish passage. While restoration efforts for salmonid habitat below dams typically focus on reoperation of dams to produce more suitable flows, dam removal is increasingly an option, especially for dams that no longer serve their original purposes well (Kiernan et al. 2012).

Here, we explore the relationship between dam removal and salmonid conservation in California, focusing on dams that act as complete barriers to anadromy (as in Sheer and Steel 2006). Specifically, we (1) review potential positive and negative effects of dam removal on anadromous salmonids, (2) describe factors which must be considered for dam removal in
California, (3) propose a method to evaluate benefits and detriments that dam removal poses to salmonids, (4) apply this method to evaluate potential benefits/ detriments of removing 24 dams, and (5) discuss the potential impacts of removing four dams on the Klamath River. We recognize there are also socioeconomic effects (e.g., Born et al. 1998; Johnson and Graber 2002; Robbins and Lewis 2008) of dam removal and salmonid conservation (e.g., to commercial and tribal fisheries) but do not discuss them here.

Review: effects of dams on anadromous salmonids

Dams disrupt movement of water, sediment, nutrients and biota between upstream and downstream habitats (Knighton 1998; Poff et al. 2007; Arthington 2012), thus altering many key processes in riverine ecosystems that are important to salmonids (Kondolf 1997; Poff et al. 1997; Poff and Hart 2002). The magnitude of these effects on anadromous salmonids depends largely on dam size, location, and operation (e.g., flow 
releases), and whether the dam is passable to salmonid migration (Collins 1976; Raymond 1988). Here, we briefly review major effects dams have through the creation of reservoirs and downstream changes in habitat, as well as impacts of hatcheries that are created to mitigate for loss of habitat above dams. Effects that are rare in California are not discussed (e.g., gas supersaturation; Beeman and Maule 2006).

\section{Reservoirs}

Although some salmonids have adapted successfully to use reservoirs to complete their life cycle (e.g. Chinook salmon in the Snake River; Connor et al. 2005), changes in stream flow and velocity associated with reservoirs can interfere with migration patterns (Tiffan et al. 2009; Pavlov et al. 2008). Adults migrating upstream through reservoirs can have difficulty finding spawning streams, while downstream migrating juveniles often encounter high predation and limited food resources (Rieman et al. 1991; Beauchamp et al. 1999; Carey et al. 2011). The impact of reservoirs on salmonids differs by location and in some cases they do not impede migration (USDOI and USDOC-NMFS 2012). However, most large dams in California do not have fish passage over them. As an alternative to fish passage, mitigation hatcheries were built downstream of many large dams in California, and at least six species of salmonids have been planted in reservoirs to support in-reservoir fisheries (Moyle 2002).

\section{Downstream effects}

The reduction of peak flows commonly observed below dams has a broad range of effects on downstream habitat that adversely affect salmonids and other stream biota. Reductions in peak (geomorphic) flows and resultant encroachment by riparian vegetation can narrow channels and diminish floodplain connectivity (Kloehn et al. 2008). Isolation from floodplains reduces ecosystem productivity by limiting riparian vegetation regeneration (Jacobson et al. 2011; Benjankar et al. 2012) and the lateral movement of nutrients and organic material that support fish growth (Henery et al. 2010; Jeffres et al. 2008). Diminished peak flows limit recruitment of large wood, an important component for habitat complexity, nutrient retention, and channel stability (Bilby and
Ward 1991; Naiman et al. 2002). Because sediment from upstream sources is retained by dams, streambeds downstream become coarser or armored, hindering excavation of redds by spawning salmonids (Knighton 1998; Poff and Hart 2002; Morley et al. 2008). In an embedded reach, spawning success is further reduced by accumulation of fine sediment in gravel that is normally flushed out by more frequent and larger flows (Louhi et al. 2011; Jensen et al. 2009). These substrate changes can reduce the abundance of macroinvertebrate prey for juvenile salmonids (Marchetti et al. 2011; Carlisle et al. 2010). In contrast, large flow releases from dams can result in channel incision in which substrates are scoured and sediment recruitment is disrupted by the dam (Kondolf 1997). Large fluctuations in dam releases over short time frames can increase fish mortality through stranding when high flows drop faster than salmonids are able to move (reviewed in Young et al. 2011).

Dam operations often reduce downstream habitat suitability by shifting water temperatures. Reservoirs create a large exposed surface area that absorbs solar radiation. If warm surface water from the reservoir is released, dams will increase downstream water temperatures (Risley et al. 2010), particularly in summer, when flows are lowest. Lower base flows and warmwater releases can reduce the amount of available habitat, increase the metabolic demands of fishes, and disrupt fish migration patterns (reviewed in Bednarek 2001; Olden and Naiman 2010). Warm water can also facilitate the spread of disease (Okamura et al. 2011; Kocan et al. 2009). Some larger dams, however, release cold water from the bottom of reservoirs. Coldwater releases that maintain or increase downstream base flows will usually reduce water temperatures in summer and fall (Huang et al. 2011; Yates et al. 2008), effectively shifting cold-water rearing habitat for juvenile anadromous salmonids from headwaters to below reservoirs (Ward and Stanford 1983). Coldwater releases are often crucial for sustaining remnant salmonid populations. For example, endangered winter run Chinook salmon $O$. tshawytscha in the Sacramento River are maintained entirely by coldwater flows from Shasta Dam, which prevents access to their former habitats (Moyle 2002). However, reliance on cold-water releases to protect salmon can be a problem if there is insufficient cold water in the reservoir to keep temperatures cool during late summer or during periods of drought (e.g., Thompson et al. 
2011). Cooler temperatures can also delay juvenile migration cues and slow juvenile growth (Xu et al. 2010; Moyle and Cech 2004).

\section{Hatcheries}

Hatcheries are often constructed to mitigate for loss of upstream spawning and rearing habitat when dams obstruct migration or otherwise reduce salmonid populations. Hatcheries have often successfully maintained salmon fisheries for long periods of time, but at a cost of reduced genetic diversity, domestication of hatchery stocks, and major impacts on wild populations. Hatchery supplementation can result in significant differences between hatchery-produced and wild salmonids with respect to evolutionary fitness (Araki et al. 2008; Reisenbichler and Rubin 1999), phenotype (Hjort and Schreck 1982; Knudsen et al. 2006; Kostow 2004), behavior (Dittman et al. 2010; Melnychuk et al. 2010), and physiology (Shrimpton et al. 1994; Chittenden et al. 2008). Abundant hatchery stocks can further impact wild populations by supporting elevated predation (Nickelson 2003) and fishing pressure (Hard et al. 2008). Hatchery operations in California have only partially compensated for the loss of habitat upstream dams and in some cases have contributed to the decline of wild salmonids (Moyle et al. 2008). For example, hatchery practices can contribute (e.g., Klamath River; Hamilton et al. 2011) or introduce disease into the wild (reviewed in Katz et al. 2013).

Review: effects of dam removal

The main goals of dam removal from a salmonid perspective are to restore natural river processes below dams and restore access to upstream habitats (Roni et al. 2002). However, dam removal will likely have short-term adverse effects; the return to geomorphic and biological processes that existed prior to dam construction will not take place immediately but at different temporal scales, assuming other upstream dams and diversions have not also altered the hydrologic regime. In the short term, stream channels are expected to narrow in the location of former reservoirs but widen below the dam as accumulated fine sediment and bedload are redistributed (Pearson et al. 2011). Salmon have spawned in newly deposited gravel just months after dam removal (e.g., Chinook salmon in the Rogue River; Vial 2012), so short-term effects may be minimal. Short-term improvements to benthic habitat in the former reservoir reach will result in recovery of macroinvertebrate abundance and biomass, but standing stocks similar to those prior to dam construction may take many years to achieve (Orr et al. 2008; Hansen and Hayes 2011).

Over the long-term (decades), stream substrate composition will become more heterogeneous (Kloehn et al. 2008). Bed loads of natural materials will encourage lateral migration of the stream channel, increasing habitat diversity and connectivity to the river floodplain (Kloehn et al. 2008), assuming downstream habitats are not constrained by levees and bank armoring. Restoration of naturally dynamic flows can increase native fish abundance where nonnative fishes are few or removed (Marks et al. 2010). Upon dam removal, anadromous salmonids will likely recolonize newly accessible habitats (Anderson and Quinn 2007; Brenkman et al. 2008b; Nicole 2012; Engle et al. 2013), facilitating the return of locally extripated species. Dam removal also may increase life history diversity as run-types such as spring run Chinook salmon recolonize upstream reaches or populations isolated above the dams reestablish anadromy (Brenkman et al. 2008b). Life history diversification coupled with increased carrying capacity (Pess et al. 2008) is likely to build more resilient populations with higher fisheries productivity (Burroughs et al. 2010). Restored connectivity and fish migration to diverse habitats, including spring-fed habitats, have the potential to contribute to more resilient populations and buffer the impacts of climate change (Hamilton et al. 2011).

Nonetheless, dam removal also represents a significant disturbance that can adversely affect the ecology of rivers and their watersheds (Catalano et al. 2007; Online Resource 1). Immediately after dam removal, large quantities of impounded fine sediments may mobilize (Mussman et al. 2008) and deposit downstream (Chang 2008). High turbidity from entrained fine sediments can disrupt fish migrations and fill interstitial spaces in the substrate to the detriment of embryos incubating in the gravel (Pess et al. 2008). Moreover, increased fine sediment deposition can decrease benthic invertebrate production in the short term (Orr et al. 2008). Toxic materials (e.g., mercury) locked in reservoir sediments may become suddenly available to contaminate food webs and inhibit nutrient cycling (as in Colas et al. 2013). 
Where reservoir releases support cold-water fisheries, dam removal may reduce or eliminate spawning and rearing habitat immediately downstream (e.g., winter Chinook salmon habitat downstream Shasta Dam; Moyle et al. 2008). The draining of a reservoirs results in the loss of lentic habitat and may decrease overall species richness and diversity of the river system (Catalano et al. 2007), although in California most reservoir fishes and many invertebrates are alien species (Moyle 2002). Removal of migration barriers in some situations has the potential to spread disease through interactions of fishes in stream reaches previously separated by dams (Brenkman et al. 2008a) and increase the vulnerability of populations to previously segregated invaders and predators (Stanley et al. 2007).

Review: factors affecting dam removal in California

General frameworks exist to assess the ecological benefits and detriments of dam removal (Hart et al. 2002; Whitelaw and MacMullan 2002; Yang et al. 2011; Zheng and Hobbs 2013). However, not all elements presented in these studies are applicable to dam removal in areas with Mediterranean climate such as California. Here, we discuss the distinct suite of factors that are particularly relevant for evaluating dam removal in California and similar areas: water infrastructure, sediment accumulation, mercury deposition, and climate change effects. The effects from these factors can be significant stressors to salmonid conservation and may be augmented by dam removal.

\section{Water infrastructure}

California has been called the 'hydraulic society' due to its vast water infrastructure, designed to move water from places and times of abundance to those of scarcity (Hundley 2001). Most large watersheds contain multiple dams that range in size from small dirt dams on headwater streams to major edifices on mainstem river. When multiple dams occur on a single river, consideration must be given to the location of each dam relative to other dams in order to evaluate removal benefits, because remaining structures may continue to degrade habitats and restrict connectivity to upstream areas (Musil et al. 2012; Grantham and Moyle 2013).
A particular problem in California is transfer of water to other basins via aqueducts. These transfers dramatically alter flow regimes of both diverted and receiving streams. In source basins (e.g., Trinity River), up to $90 \%$ of stream flow is diverted, resulting in hydrographs that are dramatically smaller and less variable relative to historical (natural) conditions (Hanak et al. 2011). In receiving basins (e.g., Sacramento River from the Trinity River), flows are augmented in summer, thus improving water quality for salmonids. Therefore, dam removal may directly benefit salmonids via increased stream flow in the source river, while paradoxically impacting salmonids by removal of water from the receiving basin. Thus, on California's north coast, water diverted from the Eel River to the Russian River is associated with declines of salmonids in the Eel River but increases in the Russian River (Yoshiyama and Moyle 2010).

\section{Accumulated sediment}

Reservoirs behind dams frequently contain large amounts of accumulated sediment and this problem is particularly acute in California. While high sedimentation rates in southern California are a natural consequence of the area's erosive geology, in northern California, hydraulic mining, used extensively during the Gold Rush, delivered massive sediment loads to aquatic habitats for nearly 50 years. San Francisco Bay, for example, experienced an order of magnitude increase in sediment transport from 1.5 to $14 \times 10^{6} \mathrm{~m}^{3} /$ year (van Geen and Luoma 1999). The excess sediment flooded towns and agricultural fields and impeded river navigation (James 2005). While hydraulic mining was eventually banned, many reservoirs in northern California continue to retain mining sediment from the 19th and early 20th centuries. In addition, natural processes continue to re-work and release mine tailings into streams, adding to the sediment load (Childs et al. 2003).

Given the large quantities of sediment trapped behind many dams, mobilization of this material following dam removal has the potential to be devastating to downstream habitat and all life stages of anadromous salmon, at least in the short-term (Kemp et al. 2011). During migrations, high loads of suspended fine sediment can damage gills, increase physiological stress, and significantly alter behavior patterns (e.g., migration timing; Bjornn and Reiser 
1991; reviewed in Newcombe and MacDonald 1991). During egg incubation, fine sediment incorporated in redds decreases substrate permeability resulting in reduced growth, disrupted development, and mortality of embryos (reviewed in Jensen et al. 2009). Moreover, fine sediments can cap redds and prevent fry from emerging. During rearing, juveniles feeding in turbid waters are often smaller than conspecifics in less turbid conditions due to decreased prey capture rates (reviewed in Kemp et al. 2011). Gill abrasion from suspended sediment during juvenile development can result in reduced ability to osmoregulate (Shrimpton et al. 2007). Indirect effects of high fine sediment concentrations (e.g., via loss of riparian vegetation, or filling of interstitial spaces) can further impair juvenile survival and growth by increasing the risk of predation due to loss of cover and altering of food web structure and productivity; even modest increases in streambed fine sediment (i.e. $20 \%$ ) are harmful to juvenile salmonids rearing in rivers (Suttle et al. 2004). However, in some situations, populations have recovered quickly from catastrophic fine sediment input (e.g., steelhead in Mount St. Helens streams after volcanic eruption; Bisson et al. 1988) and salmonids have been shown to avoid high turbidity (e.g., Bisson and Bilby 1982).

\section{Mercury deposition}

Mobilization of mercury that has accumulated in reservoir sediments is a major environmental concern when considering dam removal in California. Although high mercury levels occur naturally in some California watersheds, an estimated 4.5 million kilograms of mercury were released into California streams as a by-product of hydraulic mining during the California Gold Rush (Alpers et al. 2005). Conversion of inorganic mercury to methylmercury, a biological neurotoxin, occurs at particularly high rates in low-oxygen habitats where dissolved organic carbon is available, such as reservoirs (Domagalski 1998). Methylmercury bioaccumulates in tissues of animals (James 2005) and poses a serious health risk to organisms at higher trophic levels. Some dams were built for the express purpose of catching mining debris and have accumulated large amounts of mercurytainted sediment in their reservoirs (e.g., Englebright Dam). Therefore, the current methyl mercury load as well as conditions that might promote either mercury methylation or de-methylation need assessment prior to dam removal in California (James 2005).

\section{Climate change}

California marks the southern end of the geographic range of six species of anadromous salmonids (Table 1), likely exposing them to conditions (e.g., high summer water temperatures) near the limits of environmental tolerances. In California, climate change is degrading aquatic habitats already affected by other stressors (Battin et al. 2007) through increases in temperature, decreases in snow retention, changes in precipitation patterns, and increases in the magnitude of extreme events, such as floods and droughts (Field et al. 1999; Null et al. 2012). These changes threaten the persistence of anadromous salmonid populations (Moyle et al. 2013) and, in some cases, will strongly influence the relative benefits and detriments of dam removal for salmonids.

Although water temperatures under future climate change scenarios may exceed salmonid tolerance limits in the lower reaches of streams during the warmer months of the year, mainstem habitats will continue to serve as migration corridors during winter, with cooler headwater streams offering the only suitable habitat in the system (Crozier et al. 2008). Consequently, habitat connectivity will become as important as habitat quantity or quality (Isaak et al. 2007) in conserving California salmonids. In some instances, dam removal may be the only option to provide anadromous salmonids with access to suitable cold-water habitats including high-elevation tributaries and spring-fed streams that would be buffered from warming impacts of climate change.

Conversely, water releases from cold, thermallystratified depths present in some existing reservoirs may provide cold-water habitat downstream of dams and mitigate the effect of elevated air temperatures (Poff and Hart 2002). Such water releases can favor cold-water species immediately below the dam (Poff and Hart 2002) and affect riverine community composition for many kilometers downstream (reviewed in Haxton and Findlay 2008). However, cooling effects from dam releases differ by reservoir size and location (i.e. elevation and latitude; Null et al. 2014). Summer water releases can also augment seasonal low flows in areas where groundwater pumping lowers water tables or dries stream reaches (Constantz and 
Table 2 Scoring rubric for evaluating benefits of dam removal for salmonid conservation

\begin{tabular}{ll}
\hline & Score \\
\hline
\end{tabular}

1. Characteristics of salmonid taxa

a. Number of taxa that may benefit or number of endemics

None

1 taxon/ $\geq 1$ also found in other locations

2 taxa/taxa in only one other location

$3+$ taxa/only found in removal watershed

b. Status of source population(s)

Extirpated

Most small and or declining

Stable or increasing

Abundant

c. Life history diversity of source population(s)

Extirpated

Single life history pattern dominates

Some runs/patterns lost

All historic life histories represented

2. Quality and quantity of aquatic habitat

a. Migration barriers below dam

Barriers exist near or downstream dam

Multiple permanent barriers in watershed

Seasonal or partial barriers exist

No additional barriers

b. Habitat suitability above dams

No suitable habitat exists

Limited or degraded habitat exists

Suitable but slightly degraded habitat

Habitat in good condition

c. Amount of spawning and rearing habitat above dam

None

$<30 \%$ of former habitat

$30-50 \%$ of former habitat

$>50 \%$ of former habitat

3. Stressors to salmonid recovery

a. Number of additional limiting stressors (excluding hatcheries)

Stressors cannot be overcome

$>5$ additional stressors

2-5 additional stressors

0 or 1 additional stressor

b. Duration of adverse impacts from dam removal

Indefinite or long-term

Longer than 2 years
Table 2 continued

\begin{tabular}{lc}
\hline & Score \\
\hline 1-2 years & 2 \\
$<1$ year & 3 \\
c. Extent of hatchery supplementation & \\
Entirely reliant on hatcheries & 0 \\
$>70 \%$ of taxa supplemented & 1 \\
$30-70 \%$ of taxa supplemented & 2 \\
$<30 \%$ of taxa supplemented & 3 \\
\hline
\end{tabular}

See text for explanation

Essaid 2007). Augmentation of flows may be particularly important for providing suitable salmonid habitat as water demands increase with human population growth (Tanaka et al. 2006). However, if available cold water cannot simultaneously meet human water demands and maintain stream flows in particularly dry years, salmonid populations may be extirpated (e.g., adult spring-run Chinook in Butte Creek; Thompson et al. 2011). Under such conditions, cold water combined with favorable habitat conditions may create an 'ecological trap' in which juvenile salmonids are attracted to cold flows during rearing and later die when cold-water releases are curtailed and temperatures become too warm (Jeffres and Moyle 2012).

\section{Methods \\ Rating the effects of dam removal}

We developed a simple, flexible rating system to rapidly assess the relative magnitude of impacts from dam removal (Table 2), considering both positive and negative impacts that dam removal may have on anadromous salmonids over different spatial and temporal scales (see Online Resource 1). We intend this rating system to serve as a first step in a dam removal evaluation process and as a way to prioritize dams for removal. The system scores nine metrics relating to the characteristics of salmonid populations, habitat quality, and stressors in the watershed of interest. Benefits from dam removal were considered to be none or limited (scores $=0-9$ ), moderate (scores $=10-18)$, or high (scores $=19-27$ ) based on the sum of metric scores. The system was designed to encompass issues that are generally applicable to 
most dams that prevent fish passage in Mediterraneanclimate rivers.

\section{Characteristics of salmonid taxa}

The first metric in Table 2 considers either the level of endemism or number of native salmonid taxa that could benefit from dam removal. If protection or restoration of endemic salmonids is a desirable goal, this metric scores 0 for no existing endemics, 1 if one or more endemics exist but are found in multiple other drainages in the region, 2 if the endemics are only found in one other drainage, and 3 if the endemics occur only in the dam-removal watershed. If protection of salmonid diversity is the desirable goal, the metric scores 0 for no taxa present, 1 for one taxa, 2 for two taxa, and 3 for three or more taxa. Flexibility in the first metric allows equal consideration between areas characterized by few but highly endemic taxa and areas containing diverse assemblages. The second metric scores the ability of likely source populations to re-colonize the newly accessible areas. A source population is defined as the population that would most likely recolonize available habitats upon dam removal. Extirpated populations score a 0, small populations or those with low densities score a 1 , stable or increasing populations score a 2, and abundant or highly dense populations score a 3 . Status for California salmonids is evaluated in Moyle et al. (2008, 2011) and Katz et al. (2013). For the third metric, life history diversity, we assumed taxa with multiple life histories (i.e. life history portfolios as in Carlson and Satterthwaite 2011), are more adaptable to changing environmental conditions than those with extirpated or hatchery-dominated runs (as in Greene et al. 2010). Extirpated populations score 0, populations with a single life history score 1, populations with potential to regain lost life histories score a 2 , and populations with all life histories intact score a 3 .

\section{Habitat quality and quantity}

For metrics pertaining to aquatic habitat, we considered accessibility, condition, and quantity of habitat upstream and downstream of dam sites. For the first metric, users must determine if other barriers are present in the system. Removal of a single dam within a basin containing multiple barriers may result in limited benefits unless a large area of habitat is made accessible and all salmonid life-stages benefit. Streams with other barriers immediately adjacent to the dam under consideration, such that little to no additional habitat will be made accessible, score 0 ; streams with multiple remaining barriers within the range of anadromy, but not immediately adjacent, score a 1; streams with additional seasonal or temporary barriers score a 2; streams with no additional barriers score a 3 . For the second metric, the quality of accessible habitat above the dam is considered (Roni et al. 2002). Dam removal may only have limited benefits if the watershed upstream has been irreversibly altered (e.g., by water diversion or urbanization). For example, streams upstream of the dam site with unscreened water diversions can result in high fish mortality due to entrainment or stranding of fish (as in Carlson and Rahel 2007). If a watershed requires extensive habitat restoration beyond dam removal, there will likely be limited benefits. Systems with no suitable habitat made available score a 0 , while systems with habitat requiring extensive restoration score a 1 , if dam removal provides access to habitat that is suitable most of the year score 2, or habitat in good condition year round (including cold-water springs) score a 3 . The third metric scores the proportion of former spawning and rearing habitat reopened to anadromous salmonids. Habitats that function primarily as adult migration corridors are not considered here. In cases where multiple salmon taxa are present, the amount of habitat made available to the furthest migrant is estimated, usually for steelhead in California. Sheer and Steel (2006) used stream gradients to define general and optimal habitat for Chinook salmon and steelhead; Chinook salmon generally will use gradients from 0 to $7 \%$ (optimal at 1-2 \%), while steelhead use gradients 0-12\% (optimal at 1-5\%). Coho salmon $O$. kisutch use shallower gradients than Chinook because they do not often migrate as far inland, especially in California (Groot and Margolis 1991). Sheer and Steel (2006) determined that barriers had large, moderate, and limited impacts on steelhead and Chinook salmon distribution in the Willamette and Lower Columbia River basins, Oregon, when they blocked $>50,30-50$, and $<30 \%$ of optimal habitat, respectively. We therefore used stream gradients above dams for estimating the proportion of high quality habitat accessible to different taxa upon dam removal. We used the thresholds 
determined by Sheer and Steel (2006) in our rating system because salmonids in Oregon and California have overlapping habitat requirements (Groot and Margolis 1991). Systems with no spawning or rearing habitat upstream of the dam score a 0 , systems with $<30 \%$ of former habitat score a 1 , systems with $30-50 \%$ of former habitat score a 2 , and systems with $>50 \%$ of former habitat score a 3 .

\section{Stressors}

In addition to current habitat impairment, watersheds in California are subject to ongoing anthropogenic stressors that may limit the potential for salmonid populations to recover following dam removal [e.g., stream sedimentation, mercury accumulation, estuarine alteration, etc.; see Katz et al. (2013) for a list of 15 stressors evaluated]. Our stressor metric scores a 0 if one or more stressors clearly prevent habitat recolonization (e.g., chronic source of pollution such as acid mine drainage) or population expansion, scores a 1 where greater than five stressors were identified in the watershed, a 2 for $2-5$ stressors, and a 3 for one or no stressors.

A particular stressor that we considered separately is the dam removal process itself which can represent a large disturbance (Stanley and Doyle 2003). Dam removal that is likely to result in permanent unfavorable downstream changes (e.g., scour the stream channel to bedrock) would score a 0 . Metric scores increase with decrease in time to recovery. Adverse impacts lasting more than 2 years but expected to disappear over time score a 1, impacts lasting 1-2 years score a 2, and impacts expected to last $<1$ year score a 3 .

The third metric concerns the degree of influence of hatcheries on salmonid populations in the system. We address this stressor separately because hatchery production can alter population characteristics intrinsically (e.g., genetics or fitness) as well as extrinsically (competition with and predation on wild fish). Several studies (reviewed in Katz et al. 2013) have shown that species persistence can be threatened at different levels based on the magnitude of hatchery supplementation (including juvenile releases and adult straying) in a system. In systems where salmon runs are constantly supplemented by hatcheries, dam removal may only have limited initial benefits because fishes may already have lost key adaptations to former habitat (e.g., run timing). In such situations, redevelopment of local adaptations is likely to take multiple generations. Accordingly, benefits may be intermediate in systems with partial hatchery supplementation but high where hatchery supplementation is absent or supplementation has been managed in small conservation hatcheries over short duration (Lackey et al. 2006). Systems with taxa largely reliant on hatchery supplementation score a 0 , while systems with $>70$, $30-70,<30 \%$ hatchery-supplemented populations score a 1,2 , or 3 .

\section{Certainty}

A score of certainty is also given to each metric. A score of 1 represents limited knowledge based primarily on expert opinion. A score of 2 reflects moderate knowledge supported with a few papers and reports, usually from gray literature. High degree of certainty, a score of 3, is largely based on peerreviewed publications (e.g., Yoshiyama et al. 2001) and high familiarity of the system by the scorers. An overall certainty score for each dam removal is calculated as the average of the certainty scores for all metrics.

Application of the rating system

We first selected eight dams as case studies of dam removal for salmon conservation, based on recommendations by Hanak et al. (2011; Table 3) and the personal knowledge of one or more of the authors with these sites. These dams have all been considered for removal at one time or another. The eight dams studied in detail were Scott, Englebright, Matilija, Rindge, and the lower four dams on the Klamath River (Iron Gate, Copco 1, Copco 2, and J.C. Boyle dams; Fig. 2). Although J.C. Boyle is located in Oregon, just north of the California border, we include it here because it is part of a complex of four dams formally proposed for removal on the Klamath River. The context of each of the case studies is described below. An additional 16 large dams (see Online Resource 2 for characteristics) which are complete migration barriers to salmonids, but are not currently candidates for removal, were also rated (Online Resource 3). These dams were chosen on the basis of location, size, and their consideration for reoperation to improve habitat conditions for salmonids (i.e. environmental flows; T. Grantham, unpublished data). 
Table 3 Evaluation of potential benefits of proposed dam removal in five California watersheds

\begin{tabular}{|c|c|c|c|c|c|}
\hline $\begin{array}{l}\text { Dam } \\
\text { Watershed }\end{array}$ & $\begin{array}{l}\text { Scott } \\
\text { Eel River }\end{array}$ & $\begin{array}{l}\text { Englebright } \\
\text { Yuba River }\end{array}$ & $\begin{array}{l}\text { Rindge } \\
\text { Malibu Ck. }\end{array}$ & $\begin{array}{l}\text { Matilija } \\
\text { Matilija Ck. }\end{array}$ & $\begin{array}{l}\text { Iron Gate }+3^{\mathrm{a}} \\
\text { Klamath River }\end{array}$ \\
\hline \multicolumn{6}{|l|}{ Metric } \\
\hline 1a & 3 & 3 & 1 & 1 & 3 \\
\hline $1 b$ & 1 & 1 & 1 & 1 & 2 \\
\hline $1 \mathrm{c}$ & 2 & 2 & 1 & 1 & 2 \\
\hline $2 a$ & 2 & 2 & 3 & 2 & 2 \\
\hline $2 b$ & 2 & 2 & 2 & 2 & 2 \\
\hline $2 c$ & 1 & 3 & 3 & 3 & 2 \\
\hline $3 a$ & 2 & 3 & 2 & 2 & 2 \\
\hline $3 b$ & 1 & 0 & 3 & 1 & 2 \\
\hline $3 c$ & 3 & 1 & 3 & 3 & 1 \\
\hline Score & 17 & 17 & 19 & 16 & 20 \\
\hline Category & M & M & $\mathrm{H}$ & M & $\mathrm{H}$ \\
\hline Certainty & 3 & 3 & 3 & 3 & 3 \\
\hline
\end{tabular}

For metrics, see Table 2. Categories of benefits from dam removal: $H$ high (scores $=19-27), M$ moderate (scores $=10-18), L$ none or limited (scores = 0-9)

a Copco 1, Copco 2, J.C. Boyle dams

\section{Scott Dam}

Cape Horn Dam was built in Mendocino County as part of the Potter Valley Project on the Eel River, approximately $290 \mathrm{~km}$ from the ocean, to divert water into the Russian River. The reservoir quickly filled with sediment and, in 1921, Scott Dam (Lake County) was constructed upstream of Cape Horn Dam to increase storage capacity and provide hydropower (Pejchar and Warner 2001). Reduced flows in the mainstem river, coupled with widespread habitat degradation by logging, flooding, and mining (Pejchar and Warner 2001) and the introduction of the predatory Sacramento pikeminnow Ptychocheilus grandis resulted in a greater than $99 \%$ reduction in historical salmonid populations (Yoshiyama and Moyle 2010). While Cape Horn Dam has a functional fish ladder, Scott Dam does not and it prevents runs of Chinook salmon, coho salmon and steelhead trout from reaching $\sim 93 \mathrm{~km}$ of potential habitat (Yoshiyama and Moyle 2010). The amount of accessible habitat, however, is lower during periods of low flow when functionality of the ladder at Cape Horn dam is compromised (Yoshiyama and Moyle 2010). The inter-dam reach (between Scott and Cape Horn dams) is an important rearing area for steelhead even at low flows because cold-water releases from Scott Dam are present all summer (Yoshiyama and Moyle 2010).

\section{Englebright Dam}

Englebright Dam, located in Yuba and Nevada counties, was built in 1941 on the Yuba River, just downstream of the point where the North, Middle, and South Yuba rivers join together to form the main river. It is located approximately $314 \mathrm{~km}$ upstream from the Pacific Ocean. The dam was constructed for hydropower generation and mining debris containment, although hydraulic mining ceased upstream shortly after construction. Today, its reservoir is $25 \%$ filled with mercury-tainted sediment that continues to accumulate in the reservoir (Childs et al. 2003). Another debris dam, Daguerre Point Dam, $16 \mathrm{~km}$ downstream, has a fish ladder allowing fish passage up to Englebright Dam. The absence of fish ladders on Englebright Dam makes it a barrier to anadromous fishes; blocking access to $\sim 160 \mathrm{~km}$ of potential spawning and rearing habitat (USGS 2004). Yoshiyama et al. (2001) indicate that $70 \%(90 \mathrm{~km})$ of historically available spawning habitat for Chinook salmon and steelhead has been cut off by the dam. 
Fig. 2 Dam removal sites evaluated for effects on anadromous salmonid conservation in California

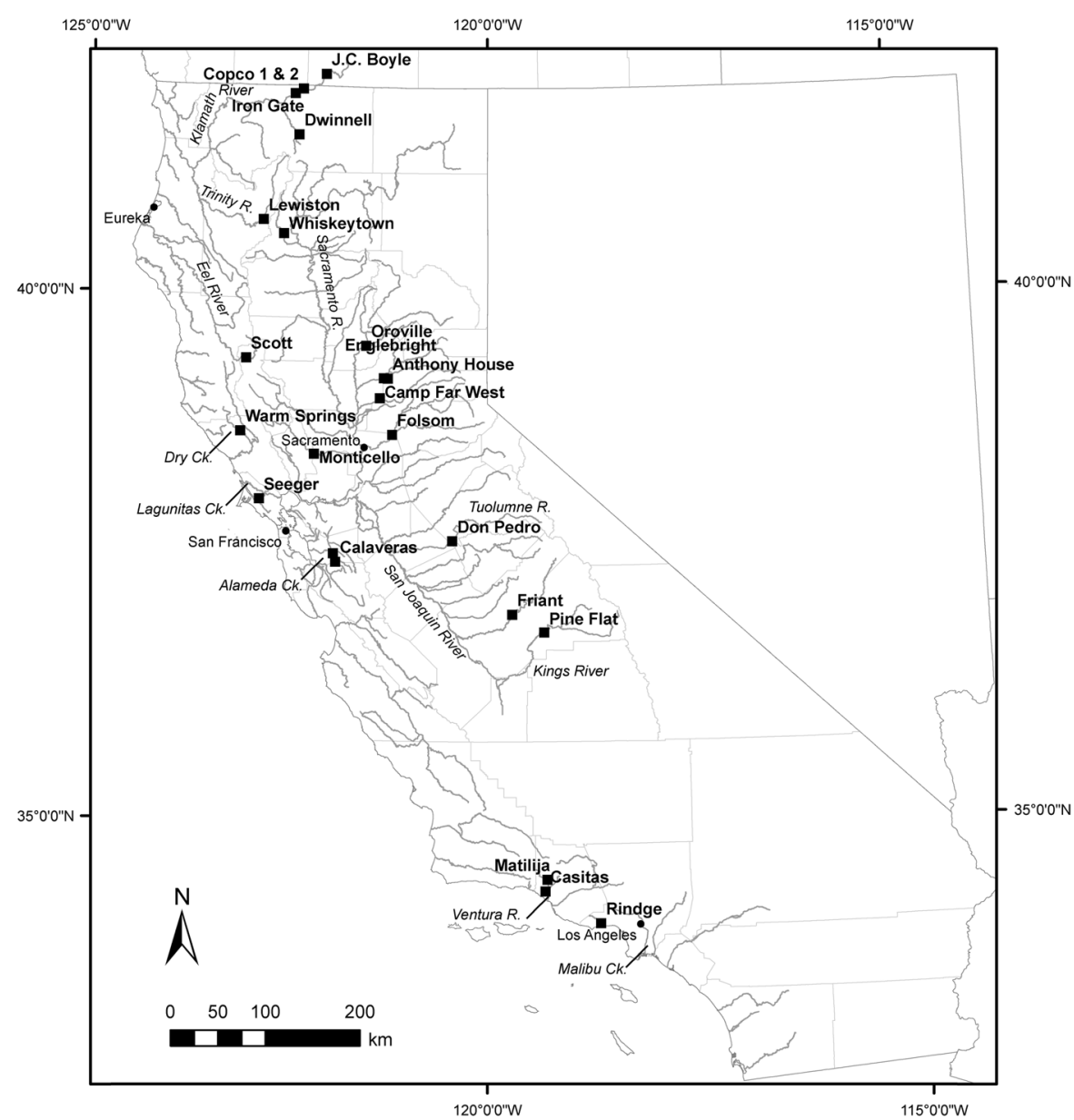

\section{Matilija Dam}

Matilija Creek, located in Ventura County approximately $27 \mathrm{~km}$ from the ocean, is a major tributary to the Ventura River. Matilija Dam was built in 1947 on Matilija Creek for water storage and flood control. However, due to the high natural erosion rates of the region, the dam has trapped more than $2.5 \times 10^{6} \mathrm{~m}^{3}$ of sediment, completely filling the reservoir (Slagel and Griggs 2008). Trapped sediments were once important for creating and maintaining channel structure and fish spawning habitat downstream (Jenkin 2009). Additionally, use of construction materials of poor quality resulted in structural weakening of the dam (Minear 2003). The Ventura River watershed historically supported large runs of southern steelhead (Allen et al. 2007), but prime spawning and rearing habitat became severely limited following construction of three large dams: Matilija, Casitas, and Robles
Diversion dams. Furthermore, altered flow and sediment transport regimes have substantially degraded the quality of accessible habitat (Becker et al. 2010). Matilija Dam is currently the upstream-most barrier to habitats that historically provided more than half of the spawning and rearing habitat in the system (P. Moyle and R. Quiñones, personal observations).

\section{Rindge Dam}

Rindge dam was built in 1926 on Malibu Creek in Los Angeles County for private water supply; its reservoir was completely filled with sediment by 1955 (Courter 2002). The estimated $0.6-1.2 \times 10^{6} \mathrm{~m}^{3}$ of sediment currently trapped behind the dam historically balanced shoreline erosion at the creek's mouth, which supports an estuary that provides habitat for several listed species (e.g., tidewater goby Eucyclogobius newberryi, willow flycatcher Empidonax traillii; M. Capelli, 
NMFS, unpublished observations). Rindge Dam is located just $4.4 \mathrm{~km}$ inland from the coast, leaving little spawning and rearing habitat accessible to endangered southern steelhead populations in Malibu Creek. Removal of the dam would about triple the amount of quality habitat available to steelhead (Abramson and Grimmer 2005).

\section{Iron Gate, Copco 1, Copco 2, and J.C. Boyle Dams}

Between 1911 and 1962, six dams were built on the mainstem Klamath River: three in Klamath County, Oregon (Link River, Keno, and J.C. Boyle) and three in Siskiyou County, California (Copco 1, Copco 2, and Iron Gate). The downstream-most dam, Iron Gate Dam, is approximately $308 \mathrm{~km}$ from the ocean. The primary functions of these dams are to impound and divert water (Link River and Keno dams), or to generate hydropower (J.C. Boyle, Copco 1, Copco 2, Iron Gate dams). Only Link River and Keno dams, the two most upstream structures, have fishways that facilitate salmonid passage. As a result, approximately $675 \mathrm{~km}$ of potential migration, rearing and spawning habitat are currently inaccessible to anadromous salmonids in the basin (Hamilton et al. 2011), although not all this habitat is likely suitable (P. Moyle and R. Quiñones, personal observations). As a condition for a hydropower relicensing, the Departments of Interior and Commerce prescribed mandatory fishways at the lower four dams to provide upstream access to migrating anadromous fishes. This has resulted in agreements (USDOI and USDOC-NMFS 2012) to decommission the lower four dams because of the high cost of building fishways.

\section{Results and discussion}

Using the rating system, we evaluated the benefits and detriments of removing 24 dams, including potential negative impacts of dam removal not always considered in previous assessments. None of the dams are currently passable for salmon. In our case, the goal was to prioritize dam removal for the conservation of salmonid diversity, as it pertains to metric 1a. Removal of twelve (50\%) of the dams evaluated seems to result in at least a moderate advance in salmonid conservation due to the large number of salmonids that would benefit or the amount of habitat that would become accessible. All eight of the dams with proposals for removal show moderate to high benefits for salmonids. For example, the moderate benefits of removing Scott Dam $($ score $=17$ ) were largely based on the number of salmonid taxa found in the Eel River (1a), the quantity (2c) of habitat upstream of the dam, and the few negative effects expected from dam removal (3b). Benefits were diminished by the status of declining salmonid populations; for instance, runs of spawning Chinook salmon in the entire Eel River basin have decreased from an estimated 56,000 to 1,000 individuals (Yoshiyama and Moyle 2010). Sacramento pikeminnow are also a major stressor that may inhibit the recovery of anadromous salmonids in the Eel River (Yoshiyama and Moyle 2010). Although several salmonids species exist in the Yuba River (1a), benefits from removing Englebright Dam would likely be moderate (score $=17$ ) due to the status of existing populations ( $1 \mathrm{~b}$; declining), high concentrations of fine sediment already in the mainstem Yuba River (2b) as well as by the large volume of mercury-tainted sediment (James et al. 2009) that would be released upon removal (3b). Additional barriers (2a) and hatchery supplementation ( $3 \mathrm{c}$ ) also likely decrease the ability of salmonids to recover. However, large portions of formerly occupied habitat could be made accessible to some taxa upon dam removal (e.g., $>80 \%$ for spring-run Chinook salmon; NMFS 2012).

The high and moderate benefits of removing Rindge ( score $=19$ ) and Matilija (score $=16$ ) dams were due to the quantity (2c) of habitat upstream of the dams, the limited duration of adverse effects expected from dam removal (3b), usually $1-5$ years (as in Hamilton et al. 2011), and the lack of hatchery supplementation in these systems (3c). Removal of the four Klamath dams (score $=20$ ) would likely have high benefits to all existing salmonid taxa (1a), all with intact life histories (1c) due to the short duration of adverse impacts from dam removal (3b; Hamilton et al. 2011). However, net benefits in the Klamath River were diminished by the magnitude of other stressors in the system (3a), including additional barriers $(2 \mathrm{a}$; i.e. seasonally poor water conditions in reaches near Kendo dam) and land use practices that decrease the suitability of habitat (2b; discussed below). The degree of hatchery supplementation (3c) for Chinook and coho salmon and steelhead trout also threaten the recovery capability of salmonids in the basin (Quiñones et al. 2013). 
Although the eight dams discussed above have been proposed for removal at one time or another, the other 16 dams we rate have not. We evaluate them here for comparison, since all are also large dams that block salmonid migration. The removal of two dams (Seeger, score $=20$; Warm Springs, score $=22$ ) could yield high benefits to salmonid conservation in California, while the removal of four (Whiskeytown, score $=6$; Monticello, score $=7$, Don Pedro Main, score $=8$; Folsom score $=8$ ) appear unlikely to have benefits. The other 10 dams were thought to advance salmon conservation at least moderately.

The high benefits of removing Seeger and Warm Springs are largely due to the protected status of these watersheds as important sources of domestic water to Marin County and the city of Santa Rosa. For this same reason, however, their removal is unlikely. The negligible benefits of removing Whiskeytown, Monticello, Folsom, and Don Pedro Main dams are a result of their location. Whiskeytown is located high in the watershed; its removal would afford little new salmonid habitat (2c). Monticello, Folsom, and Don Pedro Main dams are located near other permanent barriers (i.e. Putah Creek diversion, Nimbus dam, La Grange dam) so other dams would continue to degrade habitat and disrupt salmonid migration (2a) upon their removal. However, the likelihood of removing additional dams within the same management complex may increase once operational links between dams (e.g., Putah Creek diversion dam with Monticello dam, Folsom dam with Nimbus dam) are lost. All eight case studies received high certainty scores ( 3 ; Table 3 ) due to the abundance of literature available for each and the familiarity of at least some of the authors with these systems. Most (10 of 16) of the other 16 dams evaluated also received high certainty scores but knowledge of six was considered to be of moderate certainty. Overall, we concluded we had sufficient data to knowingly evaluate all 24 dams.

Of the dams evaluated, the Klamath dams are the only ones being formally proposed for removal at the present time. Consequently, the benefits and detriments of their removal are discussed in additional detail to illustrate the complexities of dam removal even when salmon conservation is the primary consideration. Full evaluation of Klamath dam removal effects are discussed in Hamilton et al. (2011) and USDOI and USDOC-NMFS (2012).
Klamath River case study

The Klamath River basin drains approximately $40,000 \mathrm{~km}^{2}$ in southern Oregon and northern California (Fig. 2). The Klamath basin once produced an estimated 650,000-1 million adult salmonids per year (Gresh et al. 2000) distributed across multiple species: Chinook (fall and spring runs), coho, chum O. keta and pink salmon $O$. gorbuscha and steelhead. However, abundances of runs of wild salmonids have been declining (e.g., spring-run Chinook; Nehlsen et al. 1991; NRC 2004; USDOI and USDOC-NMFS 2012).

\section{Conditions without dam removal}

In the absence of dam removal, freshwater habitats above Iron Gate Dam will remain degraded and inaccessible to anadromous fishes, unless major investment is made in fish passage facilities. Stream reaches between Keno Reservoir and Iron Gate Dam (Fig. 2) are characterized by highly-simplified flow regimes (Bartholow et al. 2004) and low water quality (e.g., low dissolved oxygen, algal blooms, high water temperature; reviewed in Hamilton et al. 2011). Furthermore, the sheer volume of water and warm temperatures in reservoirs prevent tributaries from contributing cold water to mainstem habitats (Hamilton et al. 2011). Unmodified, future operation of these dams will continue to limit the viability of fishes in areas upstream of Iron Gate Dam (Hamilton et al. 2011).

Below Iron Gate Dam, the natural flow regime and riverine processes will remain disrupted (reviewed in Hamilton et al. 2011). Construction and operation of the dams has changed the timing and magnitude of peak and base flows in the Klamath River mainstem (Stillwater Sciences 2009; Quiñones 2011), disrupting riparian plant succession, channel formation, and spawning gravel recruitment (KRBFTF 1991; FERC 2007; Varyu and Greimann 2010). These and other dam-related changes to riverine processes have contributed to conditions that foster the spread of fish disease below Iron Gate Dam (Stanford et al. 2011).

\section{Conditions with dam removal}

Our rating indicated that removal of these dams will yield benefits, supporting the conclusion of Stanford et al. (2011) that removal of the dams would be 
"ecologically beneficial to the Klamath River ecosystem (p. 157)." Our rating is independent of extensive restoration activities proposed concurrent with dam removal that will further benefit fisheries while sustaining agriculture consistent with environmental laws [as in Klamath Basin Restoration Agreement 2010 (KBRA)]. These actions are expected to greatly improve the resilience of Klamath salmonid fisheries over the next few decades (Hamilton et al. 2011). The removal of the four dams is expected to substantially improve water quality and habitat conditions in the upper basin (reviewed in Hamilton et al. 2011 and Stanford et al. 2011). Flow and temperature regimes are expected to more closely reflect historical conditions. Consequently, water that currently evaporates from reservoirs should augment flows after dams are removed (Hamilton et al. 2011). Cyanobacteria blooms, acidity, and problems associated with low dissolved oxygen are expected to diminish because nutrient cycling, uptake and transport rates are greater in lotic systems than in reservoirs (Asarian et al. 2009; Stanford et al. 2011). Water temperatures are also expected to track air temperatures more closely, so will be slightly warmer in summer but cooler in fall and winter than with dams intact (Stanford et al. 2011). There may also be some seasonal or regional cooling due to reduction in hydraulic residence time and increased riparian shading along restored river reaches (Hamilton et al. 2011). The reach that contains Iron Gate and the two Copco dams should provide high quality habitat for holding adult and rearing juvenile salmonids because several large springs provide a continuous source of cool water (Hamilton et al. 2011). Restoration of more natural flow and sediment transport regimes is expected to improve habitat diversity by moving sediment, building bars, eroding banks and toppling large woody debris into the stream channel (NRC 2007). Removal of the dams, in conjunction with KBRA, would provide anadromous salmonids access to approximately $675 \mathrm{~km}$ of additional habitat and improve the viability of all species in the system (Hamilton et al. 2011). The suitability of most of this habitat for spawning and rearing has not been closely evaluated so the amount of high quality habitat may be considerably less than the $675 \mathrm{~km}$ of accessible habitat. However, even a fraction of the newly accessible habitat could still provide significantly more spawning and rearing habitat, particularly to anadromous fishes eradicated from upstream reaches.

Removal of Klamath dams can also have negative effects on fish, mostly through short-term adverse effects on downstream aquatic habitats (Stillwater Sciences 2011; Stanford et al. 2011). Dam removal may reduce dissolved oxygen and increase turbidity levels in the short term, due to high levels of total suspended organic sediment. The worst-case scenario for salmon exposed to high fine sediment loads is of a one-time loss of production from redds in the mainstem river, potentially resulting in a loss of approximately one-third of adult fall-run Chinook spawners 3 and 4 years after dam removal (Stillwater Sciences 2008). However, the higher than normal fine sediment concentrations are not expected to impact spawning habitats beyond one year, because high flows will clean spawning gravels and remove excess organic sediments from the system. Also, formerly disrupted bedload transport will resume upon dam removal, creating and enhancing spawning habitat in former reservoir and downstream reaches (USDOI and USDOC-NMFS 2012). Over the long-term, benefits of dam removal are expected to outweigh adverse effects such that impacted populations of fall Chinook salmon are predicted to fully recover within 5 years of dam removal (Hamilton et al. 2011).

\section{Conclusions}

Dam removal is likely to improve ecosystem function and condition in most cases. However, dam removal is unlikely to restore rivers systems to predam conditions because the effects of dams are amplified through time and dam removal itself is a disturbance. On the other hand, benefits from dam removal can be enhanced by additional habitat restoration and modification of existing resource management strategies. For instance, the magnitude of benefit from the removal of Englebright Dam can be greatly increased if a viable method is found to deal with the mercury-laden sediment stored in its reservoir prior to dam removal and if releases from upstream dams can be adjusted to benefit the restored salmonid populations.

Overall, we found that most dam removals we investigated would result in at least moderate benefits to salmonid conservation. Net positive effects are 
most likely in two situations. The first is where salmonid populations below the dams are still large (e.g., fall-run Chinook salmon in the Klamath River), making them more resilient to the temporary negative impacts of dam removal such as sedimentation. The second is where populations are imperiled but adverse effects of dam removal are few (e.g., southern steelhead in Malibu Creek). The magnitude of the benefit from dam removal is therefore expected to be modulated by the conservation status of the impacted species. We assumed that large populations are more stable and able to withstand significant adverse impacts in comparison to small, imperiled populations which are likely more vulnerable. Furthermore, dam removal is likely to produce no or only marginal benefit to salmonids if additional stressors are major causes of a population's decline (e.g., hatchery supplementation, water diversions) or are preventing recovery. The four dams on the Klamath River were given special attention since they are the only ones formally being considered for removal in California at the present time. Our analysis concludes that removal of these dams can be warranted for salmonid conservation.

Our method provides a simple initial assessment of whether dam removal will benefit salmonids. However, dam removal may present benefits to other taxa and river ecosystems as a whole. For example, Bushaw-Newton et al. (2002) found that communities of aquatic insects became more diverse upon dam removal in Manatawny Creek. Freshwater mussels were also expected to benefit from dam removal through the recolonization of upstream habitats by host fishes. In the Carmel River, removal of San Clemente Dam is expected to benefit the imperiled red-legged frog Rana draytonii (CDWR 2012). Native riparian vegetation may also benefit from dam removal (Poff et al. 1997), although benefits may only manifest after long periods and in absence of invasive non-native plants (reviewed in Shafroth et al. 2002). River ecosystems overall are expected to become more resilient upon dam removal if they are not so altered as to inhibit restoration of natural conditions (e.g., Hamilton et al. 2011). However, dam removal can also present detriments to river ecosystems. In the Klamath River, dam removal is expected to increase high water temperatures in spring and early summer to harmful levels for rearing juvenile salmonids (Bartholow et al. 2004). Short-term but significant impacts from the release of sediments trapped behind dams may present the largest detriment from dam removal; trapped sediments can degrade water quality and river morphology, and negatively impact salmonids and other aquatic life for several years after dam removal (USDOI and USDOC-NMFS 2012). Consequently, the benefits and detriments of dam removal must be carefully weighed prior to implementation.

While our protocol was developed for anadromous salmonids in California's Mediterranean climate, it could easily be modified for use in other regions and for other taxa, such as freshwater mussels or other anadromous and resident fishes, bearing in mind that the characteristics of the taxa of interest, quality of aquatic habitat, and additional stressors specific to each region and river system must be considered. We can envision such species-based protocols being incorporated into a broader systematic strategy for evaluating dams as operation licenses are evaluated for renewal. Such a strategy would likely include alternative criteria, such as economic considerations, that may reach conclusions contrary to assessments focused on fish.

We recognize that economic benefits and other reasons for maintaining dams are often a priority. Yet when salmon and steelhead conservation are considered in conjunction with other potential benefits, the case for dam removal can out-weigh reasons for maintaining a dam. For example, both Matilija and Rindge dams store large amounts of sediment that, if flushed downstream, would help restore important recreational ocean beaches near their mouths. In exchange for the short-term negative impacts of sediment flushing, there could be long-term benefits to both endangered southern steelhead and to local beach-based economies.

As a final thought, we note that no dam lasts forever and most gradually become reduced in function as the reservoir fills with sediment. Ultimately, all dams will be abandoned, removed, or rebuilt, even if the time span is hundreds of years. Thus, periodic evaluation using criteria such as we have presented in conjunction with economic evaluation is a worthwhile exercise. As dams decline in economic value, the relative benefits of removal will increase.

Acknowledgments This work was partially funded by the California Landscape Conservation Cooperative. 
Open Access This article is distributed under the terms of the Creative Commons Attribution License which permits any use, distribution, and reproduction in any medium, provided the original author(s) and the source are credited.

\section{References}

Abramson M, Grimmer M (2005) Fish migration severity and steelhead habitat quality in the Malibu Creek watershed. California State Coastal Conservancy and California Department of Parks and Recreation, Oakland

Allen MA, Riley SC, Gast T (2007) Steelhead population and habitat assessment in the Ventura River/Matilija Creek basin 2006 final report. Thomas R. Payne and Associates, Arcata

Alpers CN, Hunerlach MP, May JT, Hothern RL (2005) Mercury contamination from historical gold mining in California. US Geol Surv Fact Sheet 2005-3014:1-6

Anderson JH, Quinn TP (2007) Movements of adult coho salmon (Oncorhynchus kisutch) during colonization of newly accessible habitat. Can J Fish Aquat Sci 64:1143-1154

Araki H, Berejikian BA, Ford MJ, Blouin MS (2008) Fitness of hatchery-reared salmonids in the wild. Evol Appl 1: 342-355

Arthington AH (2012) Environmental flows: saving rivers in the third millennium. University of California Press, Berkeley

Asarian E, Kann J, Walker WW (2009) Multi-year nutrient budget dynamics for Iron Gate and Copco reservoirs, California. Karuk Tribe Department of Natural Resources, Eureka

Bartholow JM, Campbell SG, Flug M (2004) Predicting the thermal effects of dam removal on the Klamath River. Environ Manag 34:856-874

Battin J, Wiley MW, Ruckelshaus MH, Palmer RN, Korb E, Bartz KK, Imaki H (2007) Projected impacts of climate change on salmon habitat restoration. PNAS 104:67206725

Beauchamp DA, Baldwin CM, Vogel JL, Gubala CP (1999) Estimating diel, depth-specific foraging opportunities with a visual encounter rate model for pelagic piscivores. Can J Fish Aquat Sci 56:128-139

Becker GS, Smetak KM, Asbury DA (2010) Southern steelhead resources evaluation: identifying promising locations for steelhead restoration in watersheds south of the Golden Gate. Center for Ecosystem Management and Restoration, Oakland

Bednarek AT (2001) Undamming rivers: a review of the ecological impacts of dam removal. Environ Manag 27: 803-814

Beeman JW, Maule AG (2006) Migration depths of juvenile Chinook salmon and steelhead relative to total dissolved gas supersaturation in a Columbia River reservoir. Trans Am Fish Soc 135:584-594

Benjankar R, Klaus J, Yager EM, Egger G, Goodwin P, Glenn NF (2012) The impact of river modification and dam operation on floodplain vegetation succession trends in the Kootenai River, USA. Ecol Eng 46:88-97
Bilby RE, Ward JW (1991) Characteristics and function of large woody debris in streams draining old-growth, clear-cut, and second-growth forests in Southwestern Washington. Can J Fish Aquat Sci 48:2499-2508

Bisson PA, Bilby RE (1982) Avoidance of suspended sediment by juvenile coho salmon. N Am J Fish Manag 2:371-374

Bisson PA, Nielsen JL, Ward JW (1988) Summer production of coho salmon stocked in Mount St. Helens streams 3-6 years after the 1980 eruption. Trans Am Fish Soc 117:322-335

Bjornn TC, Reiser DW (1991) Habitat requirements of salmonids in streams. In: Meehan WR (ed) Influences of forest and rangeland management on salmonid fishes and their habitats. American Fisheries Society, Bethesda, pp 83-138

Börk KS, Krovoza JF, Katz JV, Moyle PB (2012) The rebirth of California fish and Game Code section 5937: water for fish. UCDL Rev 45:809-913

Born SM, Genskow KD, Filbert TL, Hernandez-Mora N, Keefer ML, White KA (1998) Socioeconomic and institutional dimensions of dam removal: the Wisconsin experience. Environ Manag 22:359-370

Brenkman SJ, Mumford SL, House M, Patterson C (2008a) Establishing baseline information on the geographic distribution of fish pathogens endemic in Pacific salmonids prior to dam removal and subsequent recolonization by anadromous fish in the Elwha River, Washington. Northwest Sci 82:142-152

Brenkman SJ, Pess GR, Torgersen CE, Kloehn KK, Duda JJ, Corbett SC (2008b) Predicting recolonization patterns and interactions between potamodromous and anadromous salmonids in response to dam removal in the Elwha River, Washington state, USA. Northwest Sci 82:91-106

Burroughs BA, Hayes DB, Klomp KD, Hansen JF, Mistak J (2010) The effects of the Stronach dam removal on fish in the Pine River, Manistee County, Michigan. Trans Am Fish Soc 139:1595-1613

Bushaw-Newton KL, Hart DD, Pizzuto JE, Thomson JR, Egan J, Ashley JT, Johnson TE, Horwitz RJ, Keeley M, Lawrence J, Charles D, Gatenby C, Kreeger DA, Nightengale T, Thomas RL, Velinsky DJ (2002) An integrative approach towards understanding ecological responses to dam removal: the Manatawny Creek study. J Am Water Resour Assoc 38:1581-1600

California Department of Water Resources (CDWR) (2012) Final supplement to the San Clemente Dam seismic safety project final environmental impact report/environmental impact statement. Department of Water Resources, Sacramento

Carey MP, Sanderson BL, Friesen TA, Barnas KA, Olden JD (2011) Smallmouth bass in the Pacific Northwest: a threat to native species; a benefit for anglers. Rev Fish Sci 19:305-315

Carlisle DM, Wolock DM, Meador MR (2010) Alteration of streamflow magnitudes and potential ecological consequences: a multiregional assessment. Front Ecol Environ 9:264-270

Carlson AJ, Rahel FJ (2007) A basinwide perspective on entrainment of fish in irrigation canals. Trans Am Fish Soc 136:1335-1343

Carlson SM, Satterthwaite WH (2011) Weakened portfolio effect in a collapsed salmon population complex. Can J Fish Aquat Sci 68:1579-1589 
Catalano MJ, Bozek MA, Pellett TD (2007) Effects of dam removal on fish assemblage structure and spatial distributions in the Baraboo River, Wisconsin. N Am J Fish Manag 27:519-530

Chang HH (2008) Case study of fluvial modeling of river responses to dam removal. J Hydraul Eng 134:295-302

Childs JR, Snyder NP, Hampton MA (2003) Bathymetric and geophysical surveys of Englebright Lake, Yuba-Nevada Counties, California. US Geological Survey Open File Report 03-383:1-20, Menlo Park

Chittenden CM, Sura S, Butterworth KG, Cubitt KF, Manel-La NP, Balfry S, Okland F, McKinley RS (2008) Riverine, estuarine and marine migratory behaviour and physiology of wild and hatchery-reared coho salmon Oncorhynchus kisutch (Walbaum) smolts descending the Campbell River, BC, Canada. J Fish Biol 72(3):614-628

Colas F, Baudoin J, Danger M, Usseglio-Polatera P, Wagner P, Devin S (2013) Synergistic impacts of sediment contamination and dam presence on river functioning. Freshw Biol 58:320-336

Collins GB (1976) Effects of dams on Pacific salmon and steelhead trout. Mar Fish Rev 1222:39-46

Connor WP, Sneva JG, Tiffan KF, Steinhorst RK, Ross D (2005) Two alternative life history types for fall Chinook salmon in the Snake River basin. Trans Am Fish Soc 134:291-304

Constantz J, Essaid H (2007) Influence of groundwater pumping on streamflow restoration following dam removal. Hydrol Process 21:2823-2834

Courter C (2002) Trout coalition call for removal of Rindge Dam. Malibu Times, Malibu

Crozier LG, Hendry AP, Lawson PW, Quinn TP, Mantua NJ, Battin J, Shaw RG, Huey RB (2008) Potential responses to climate change in organisms with complex life histories: evolution and plasticity in Pacific salmon. Evol Appl $1: 252-270$

Dittman AH, May D, Larsen DA, Moser ML, Johnston M, Fast D (2010) Homing and spawning site selection by supplemented hatchery- and natural-origin Yakima River spring Chinook salmon. Trans Am Fish Soc 139:1014-1028

Domagalski J (1998) Occurrence and transport of total mercury and methyl mercury in the Sacramento River basin, California. J Geochem Explor 64:277-291

Engle R, Skalicky J, Poirier J (2013) Translocation of lower Columbia River fall Chinook salmon (Oncorhynchus tshawystcha) in the year of Condit dam removal and year one post-removal assessments. Report to US Fish and Wildlife Service, Vancouver

Federal Energy Regulatory Commission (FERC) (2007) Final environmental impact statement for relicensing of the Klamath hydroelectric Project No. 2082-027, Washington, $\mathrm{DC}$

Field CB, Daily GC, Davis FW, Gaines S, Matson PA, Melack J, Miller NL (1999) Confronting climate change in California: ecological impacts on the golden state. Union of Concerned Scientists, Cambridge

Graf WL (2006) Downstream hydrologic and geomorphic effects of large dams on American rivers. Geomorphology 79:336-360

Grantham TE, Moyle PB (2013) Assessing flows for fish below dams: a systematic approach to evaluate compliance of
California's dams with fish and Game Code Section 5937. Center for Watershed Sciences, Davis

Greene CM, Hall JE, Guilbault KR, Quinn TP (2010) Improved viability of populations with diverse life-history portfolios. Biol Lett 6:382-386

Gresh T, Lichatowich JA, Schoonmaker P (2000) An estimation of historic and current levels of salmon production in the Northeast Pacific ecosystem: evidence of a nutrient deficit in the freshwater systems of the Pacific Northwest. Fisheries 25(1):15-21

Groot C, Margolis L (eds) (1991) Pacific salmon: life histories. UBC Press, Vancouver

Hamilton J, Rondorf D, Hampton M, Quiñones RM, Simondet J, Smith T (2011) Synthesis of the effects to fish species of two management scenarios for the secretarial determination on removal of the lower four dams on the Klamath River. US fish and Wildlife Service, Yreka

Hanak E, Lund J, Dinar A, Gray B, Howitt R, Mount J, Moyle PB, Thompson B (2011) Managing California's water: from conflict to reconciliation. Public Policy Institute of California, San Francisco

Hansen JF, Hayes DB (2011) Long-term implications of dam removal for macroinvertebrate communities in Michigan and Wisconsin rivers, United States. River Res Appl 28:1540-1550

Hard JJ, Gross MR, Heino M, Hilborn R, Kope RG, Law R, Reynolds JD (2008) Evolutionary consequences of fishing and their implications for salmon. Evol Appl 1(2):388-408

Hart DD, Johnson TE, Bushaw-Newton KL, Horwitz RJ, Bednarek AT, Charles DF, Kreeger DA, Velinsky DJ (2002) Dam removal: challenges and opportunities for ecological research and river restoration. Bioscience 52(8): 669-681

Haxton TJ, Findlay CS (2008) Meta-analysis of the impacts of water management on aquatic communities. Can J Fish Aquat Sci 65:437-447

Henery RE, Sommer TR, Goldman CR (2010) Growth and methylmercury accumulation in Juvenile Chinook salmon in the Sacramento River and its floodplain, the Yolo Bypass. Trans Am Fish Soc 139:550-563

Hjort RC, Schreck CB (1982) Phenotypic differences among stocks of hatchery and wild coho salmon, Oncorhynchus kisutch, in Oregon, Washington and California. Fish Bull 80:105-119

Huang B, Langpap C, Adams RM (2011) Using instream water temperature forecasts for fisheries management: an application in the Pacific Northwest. J Am Water Resour As 47:861-876

Hundley JN (2001) The great thirst: Californians and water: a history. University of California Press, Berkeley

Isaak DJ, Thurow RF, Rieman BE, Dunham JB (2007) Chinook salmon use of spawning patches: relative roles of habitat quality, size, and connectivity. Ecol Appl 17:352-364

Jacobson R, Janke T, Skold J (2011) Hydrologic and geomorphic considerations in restoration of river-floodplain connectivity in a highly altered river system, Lower Missouri River, USA. Wetl Ecol Manag 19:295-316

James LA (2005) Sediment from hydraulic mining detained by Englebright and small dams in the Yuba basin. Geomorphology 71:202-226 
James LA, Singer MB, Ghoshal S, Megison M (2009) Historical channel changes in the lower Yuba and Feather Rivers, California: long-term effects of contrasting river-management strategies. Geol Soc Am Spec Paper 45:57-81

Jeffres C, Moyle PB (2012) When good fish make bad decisions: coho salmon in an ecological trap. N Am J Fish Manag 32:87-92

Jeffres C, Opperman J, Moyle PB (2008) Ephemeral floodplain habitats provide best growth conditions for juvenile Chinook salmon in a California river. Environ Biol Fish 83:449-458

Jenkin P (2009) Managed shoreline retreat and dam removal: ecosystem restoration to benefit coastal resources. Reef $\mathbf{J}$ $1: 140-152$

Jensen DW, Steel EA, Fullerton AH, Pess GR (2009) Impact of fine sediment on egg-to-fry survival of Pacific salmon: a meta-analysis of published studies. Rev Fish Sci 17: 348-359

Johnson SE, Graber BE (2002) Enlisting the social sciences in decisions about dam removal. Bioscience 52:731-738

Katz JV, Moyle PB, Quiñones RM, Israel JA, Purdy SE (2013) Impending extinction of salmon, steelhead, and trout (Salmonidae) in California. Environ Biol Fish 96:1169-1186

Kemp P, Sear D, Collins A, Naden P, Jones I (2011) The impacts of fine sediment on riverine fish. Hydrol Process 25: $1800-1821$

Kiernan JD, Moyle PB, Crain PK (2012) Restoring native fish assemblages to a regulated California stream using the natural flow regime concept. Ecol Appl 22:1472-1482

Klamath River Basin Fisheries Task Force (KRBFTF) (1991) Long-range plan for the Klamath River basin conservation area fishery restoration program. US Fish and Wildlife Service, Yreka

Kloehn KK, Beechie TJ, Morley SA, Coe HJ, Duda JJ (2008) Influence of dams on river-floodplain dynamics in the Elwha River, Washington. Northwest Sci 82:224-235

Knighton D (1998) Fluvial forms and processes: a new perspective. Oxford University Press, New York

Knudsen CM, Schroder SL, Busack CA, Johnston MV, Pearsons TN, Bosch WJ, Fast DE (2006) Comparison of life history traits between first-generation hatchery and wild Upper Yakima river Spring Chinook salmon. Trans Am Fish Soc 135:1130-1144

Kocan R, Hershberger P, Sanders G, Winton J (2009) Effects of temperature on disease progression and swimming stamina in Ichthyophonus-infected rainbow trout, Oncorhynchus mykiss (Walbaum). J Fish Dis 32:835-843

Kondolf GM (1997) Hungry water: effects of dams and gravel mining on river channels. J Environ Manag 21:533-551

Kostow KE (2004) Differences in juvenile phenotypes and survival between hatchery stocks and a natural population provide evidence for modified selection due to captive breeding. Can J Fish Aquat Sci 61:577-589

Lackey RT, Lach DH, Duncan SL (eds) (2006) Salmon 2100: the future of wild Pacific salmon. American Fisheries Society, Bethesda

Lindley ST, Schick RS, Agrawal A, Goslin M, Pearson TE, Mora E, Anderson JJ, May B, Greene S, Hanson C, Low A, McEwan D, MacFarlane RB, Swanson C, Williams JG (2006) Historical population structure of Central Valley steelhead and its alterations by dams. San Francisco Estuary Watershed Sci 4:1-19

Louhi P, Ovaska M, Mäki-Petäys A, Erkinaro J, Muotka T (2011) Does fine sediment constrain salmonid alevin development and survival? Can J Fish Aquat Sci 68: 1819-1826

Magilligan FJ, Nislow KH (2005) Changes in hydrologic regimes by dams. Geomorphology 71:61-78

Marchetti MP, Moyle PB (2001) Effects of flow regime on fish assemblages in a regulated California stream. Ecol Appl 11:530-539

Marchetti MP, Esteban E, Smith ANH, Pickard D, Richards AB, Slusark J (2011) Measuring the ecological impact of longterm flow disturbance on the macroinvertebrate community in a large Mediterranean climate river. J Freshw Ecol 26:459-480

Marks JC, Haden GA, O’Neill M, Pace C (2010) Effects of flow restoration and exotic species removal on recovery of native fish: lessons from a dam decommissioning. Restor Ecol 18:934-943

Melnychuk MC, Welch DW, Walters CJ (2010) Spatio-temporal migration patterns of Pacific salmon smolts in rivers and coastal marine waters. PLoS One 5:e12916

Minear JT (2003) Sediment dynamics and steelhead habitat (Oncorhynchus mykiss) in the Matilija Creek watershed, southern California. Thesis, University of California

Morley SA, Duda JJ, Coe HJ, Kloehn KK, McHenry ML (2008) Benthic invertebrates and periphyton in the Elwha River basin: current conditions and predicted response to dam removal. Northwest Sci 82:179-196

Moyle PB (2002) Inland fishes of California. University of California Press, Berkeley

Moyle PB, Cech JJ (2004) Fishes: an introduction to ichthyology. Prentice-Hall Inc., Upper Saddle River

Moyle PB, Israel JA, Purdy SE (2008) Salmon, steelhead, and trout in California: status of an emblematic fauna. Caltrout, San Francisco

Moyle PB, Katz JV, Quiñones RM (2011) Rapid decline of California's native inland fishes: a status assessment. Biol Conserv 144:2414-2423

Moyle PB, Kiernan JD, Crain PK, Quiñones RM (2013) Climate change vulnerability of native and alien freshwater fishes of California: a systematic assessment approach. PLoS One 8:e63883

Musil J, Horky P, Slavik O, Zboril A, Horka P (2012) The response of the young of the year fish to river obstacles: functional and numerical linkages between dams, weirs, fish habitat guilds and biotic integrity across large spatial scales. Ecol Indic 23:634-640

Mussman EK, Zabowski D, Acker SA (2008) Predicting secondary reservoir sediment erosion and stabilization following dam removal. Northwest Sci 82:236-245

Naiman RJ, Bilby RE, Schindler DE, Helfield JM (2002) Pacific salmon, nutrients, and the dynamics of freshwater and riparian ecosystems. Ecosystems 5:399-417

National Marine Fisheries Service (NMFS) (2012) Biological opinion for the U.S. Army Corps of Engineers' operation and maintenance of Englebright and Daguerre Point dams and Englebright Reservoir on the Yuba River. National Marine Fisheries Service, Sacramento 
National Research Council (NRC) (2004) Endangered and threatened fishes in the Klamath River basin: causes of decline and strategies for recovery. The National Academies Press, Washington, DC

Nehlsen W, Williams JE, Lichatowich JA (1991) Pacific salmon at the crossroads: stocks at risk from California, Oregon, Idaho, and Washington. Fisheries 16:4-21

Newcombe CP, MacDonald DD (1991) Effects of suspended sediments on aquatic ecosystems. N Am J Fish Manag 11:72-82

Nickelson T (2003) The influence of hatchery coho salmon (Oncorhynchus kisutch) on the productivity of wild coho salmon populations in Oregon coastal basins. Can J Fish Aquat Sci 60:1050-1056

Nicole W (2012) Lessons of the Elwha River: managing health hazards during dam removal. Environ Health Perspect 120:a430-a435

NRC (2007) Hydrology, ecology, and fishes of the Klamath River basin. National Academies Press, Washington, DC

Null SE, Viers JH, Deas ML, Tanaka SK, Mount JF (2012) Stream temperature sensitivity to climate warming in California's Sierra Nevada: impacts to coldwater habitat. Clim Change. doi:10.1007/s10584-012-0459-8

Null SE, Ligare ST, Viers JH (2014) A method to consider whether dams mitigate climate change effects on stream temperatures. J Am Water Resour Assoc 49:1456-1472

Okamura B, Hartikainen H, Schmidt-Posthaus H, Wahli T (2011) Life cycle complexity, environmental change and the emerging status of salmonid proliferative kidney disease. Freshw Biol 56(4):735-753

Olden JD, Naiman RJ (2010) Incorporating thermal regimes into environmental assessments: modifying dam operations to restore freshwater ecosystem integrity. Freshw Biol 55:86-107

Orr CH, Kroiss SJ, Rogers KL, Stanley EH (2008) Downstream benthic responses to small dam removal in a coldwater stream. River Res Appl 24:804-822

Pavlov D, Mikheev V, Lupandin A, Skorobogatov M (2008) Ecological and behavioural influences on juvenile fish migrations in regulated rivers: a review of experimental and field studies. Hydrobiologia 609(1):125-138

Pearson AJ, Snyder NP, Collins MJ (2011) Rates and processes of channel response to dam removal with a sand-filled impoundment. Water Resour Res 47(8):W08504

Pejchar L, Warner K (2001) A river might run through it again: criteria for consideration of dam removal and interim lessons from California. Environ Manag 28:561-575

Pess GR, McHenry ML, Beechie TJ, Davies J (2008) Biological impacts of the Elwha River dams and potential salmonid responses to dam removal. Northwest Sci 82:72-90

Poff NL, Hart DD (2002) How dams vary and why it matters for the emerging science of dam removal. BioScience 52:659-668

Poff NL, Allan JD, Bain MB, Karr JR, Prestegaard KL, Richter BD, Sparks RE, Stromberg JC (1997) The natural flow regime: a paradigm for river conservation and restoration. Bioscience 47:769-784

Poff NL, Olden JD, Merritt DM, Pepin DM (2007) Homogenization of regional river dynamics by dams and global biodiversity implications. PNAS 104:5732-5737
Quiñones RM (2011) Recovery of Pacific salmonids (Oncorhynchus spp.) in the face of climate change: a case study of the Klamath River basin, California. Dissertation, University of California

Quiñones RM, Johnson ML, Moyle PB (2013) Hatchery practices may result in replacement of wild salmonids: adult trends in the Klamath River basin, California. Environ Biol Fish. doi:10.1007/s10641-013-0146-2

Raymond HL (1988) Effects of hydroelectric development and fisheries enhancement on spring and summer Chinook salmon and steelhead in the Columbia River basin. N J Fish Manag 8:1-24

Reisenbichler RR, Rubin SP (1999) Genetic changes from artificial propagation of Pacific salmon affect the productivity and viability of supplemented populations. ICES J Mar Sci 56:459-466

Rieman BE, Beamesderfer RC, Vigg S, Poe TP (1991) Estimated loss of juvenile salmonids to predation by northern squawfish, walleyes, and smallmouth bass in John Day reservoir, Columbia River. Trans Am Fish Soc 120:448-458

Risley JC, Constantz J, Essaid H, Rounds S (2010) Effects of upstream dams versus groundwater pumping on stream temperature under varying climate conditions. Water Resour Res 46:W06517

Robbins JL, Lewis LY (2008) Demolish it and they will come: estimating the economic impacts of restoring a recreational fishery. J Am Water Resour 44:1488-1499

Roni P, Beechie TJ, Bilby RE, Leonetti FE, Pollock MM, Pess GR (2002) A review of stream restoration techniques and a hierarchical strategy for prioritizing restoration in Pacific Northwest watersheds. N Am J Fish Manag 22:1-20

Shafroth PB, Friedman JM, Auble GT, Scott ML, Braatne JH (2002) Potential response of riparian vegetation to dam removal. Bioscience 52:703-713

Sheer MB, Steel EA (2006) Lost watersheds: barriers, aquatic habitat connectivity, and salmon persistence in the Willamette and lower Columbia River basins. Trans Am Fish Soc 135:1654-1669

Shrimpton JM, Bernier NJ, Randall DJ (1994) Changes in cortisol dynamics in wild and hatchery-reared juvenile coho salmon (Oncorhynchus kisutch) during smoltification. Can J Fish Aquat Sci 51:2179-2187

Shrimpton JM, Zydlewski JD, Heath JW (2007) Effect of daily oscillation in temperature and increased suspended sediment on growth and smolting in juvenile Chinook salmon, Oncorhynchus tshawytscha. Aquaculture 273:269-276

Slagel MJ, Griggs GB (2008) Cumulative losses of sand to the California coast by dam impoundment. J Coast Res 243:571-584

Stanford J, Duffy W, Asarian E, Cluer B, Detrich P, Eberle L, Edmondson S, Foott S, Hampton M, Kann J, Malone K, Moyle PB (2011) Conceptual model for restoration of the Klamath River. In: Thorsteinson L, VanderKooi S, Duffy W (eds). Proceedings of the Klamath Basin science conference, Medford, pp 151-184

Stanley EH, Doyle MW (2003) Trading off: the ecological effects of dam removal. Front Ecol Environ 1:15-22

Stanley EH, Catalano MJ, Mercado-Silva N, Orr CH (2007) Effects of dam removal on brook trout in a Wisconsin stream. River Res Appl 23:792-798 
Stillwater Sciences (2008) Klamath River dam removal study: sediment transport DREAM-1 simulation. Technical report. California Coastal Conservancy, Oakland

Stillwater Sciences (2009) Dam removal and Klamath River water quality: a synthesis of the current conceptual understanding and a assessment of data gaps. Technical Report, Oakland

Stillwater Sciences (2011) Klamath dam removal drawdown scenario 8: potential impacts of suspended sediments on focal fish species with and without mechanical sediment removal, Berkeley

Suttle KB, Power ME, Levine JM, McNeely C (2004) How fine sediment in riverbeds impairs growth and survival of juvenile salmonids. Ecol Appl 14:969-974

Tanaka SK, Zhu T, Lund JR, Howitt RE, Jenkins MW, Pulido MA, Tauber M, Ritzema RS, Ferreira IC (2006) Climate warming and water management adaptation for California. Clim Change 76:361-387

Thompson LC, Escobar MI, Mosser CM, Purkey DR, Yates D, Moyle PB (2011) Water management adaptations to prevent loss of spring-run Chinook salmon in California under climate change. J Water Res Plan Manag. doi:10.1061/ (ASCE)WR.1943-5452

Tiffan KF, Kock TJ, Haskell CA, Connor WP, Steinhorst RK (2009) Water velocity, turbulence, and migration rate of subyearling fall Chinook salmon in the free-flowing and impounded Snake River. Trans Am Fish Soc 138:373-384

US Department of Interior and US Department of CommerceNational Marine Fisheries Service (USDOI and USDOCNMFS) (2012) Klamath dam removal overview report for the secretary of the interior: an assessment of science and technical information. US Geological Survey, Portland

US Geological Survey (USGS) (2004) Should Englebright dam be removed? Pacific Coastal and Marine Science Center, Santa Cruz

van Geen A, Luoma SN (1999) The impact of human activities on sediments of San Francisco Bay, California: an overview. Mar Chem 64:1-6

Varyu DR, Greimann BP (2010) Sediment mobilization analysis at Little Bogus Creek and Beaver Creek for Klamath dam removal studies. Bureau of Reclamation, Sacramento
Vial J (2012) Gold Ray Dam removal monitoring. Open River Initiative Report no. 0348-0044. NOAA, White City

Ward JV, Stanford JA (1983) Serial discontinuity concept of lotic ecosystems. In: Bartell SM, Fontaine TD (eds) Dynamics of lotic systems. Ann Arbor Science, Ann Arbor

Whitelaw E, MacMullan E (2002) A framework for estimating the costs and benefits of dam removal. Bioscience 52:724-730

Wohl E (2012) Identifying and mitigating dam-induced declines in river health: three case studies from western United States. Int J Sediment Res 27:271-287

$\mathrm{Xu}$ C, Letcher BH, Nislow KH (2010) Context-specific influence of water temperature on brook trout growth rates in the field. Freshw Biol 55:2253-2264

Yang M, Qian X, Zhang YH, Sheng JB, Shen DL, Ge Y (2011) Spatial multicriteria decision analysis of flood risks in aging-dam management in china: a framework and case study. Int J Environ Res 8:1368-1387

Yates D, Galbraith H, Purkey D, Huber-Lee A, Sieber J, West J, Herrod-Julius S, Joyce B (2008) Climate warming, water storage, and Chinook salmon in California's Sacramento Valley. Clim Change 91:335-350

Young PS, Cech Jr JJ, Thompson LC (2011) Hydropowerrelated pulse-flow impacts on stream fishes: a brief review, conceptual model, knowledge gaps, and research needs. Rev Fish Biol Fish 21:713-731

Yoshiyama RM, Moyle PB (2010) Historical review of Eel River anadromous salmonids, with emphasis on Chinook salmon, coho salmon and steelhead. University of California, Davis

Yoshiyama RM, Fisher FW, Moyle PB (1998) Historical abundance and decline of Chinook salmon in the central valley region of California. $\mathrm{N}$ Am J Fish Manag 18:487-521

Yoshiyama RM, Gerstung ER, Fisher FW, Moyle PB (2001) Historical and present distribution of Chinook salmon in the Central Valley drainage of California. Calif Dep Fish Game Fish Bull 179:71-176

Zheng P, Hobbs B (2013) Multiobjective portfolio analysis of dam removals addressing dam safety, fish populations, and cost. J Water Res Plan 139:65-75 